\title{
Fungal endophytes as the source of medicinal natural product
}

\author{
Jamur endofit sebagai sumber obat bahan alam
}

\author{
Asih Triastuti \\ Jurusan Farmasi, FMIPA, Universitas Islam Indonesia \\ Corresponding author: asih.triastuti@uii.ac.id
}

\begin{abstract}
Massive exploration of medicinal plants as a source of medicinal raw materials and high demand for traditional medicines on the market has been a threat to biodiversity and plant species. To respond to the challenge of more efficient access to chemical diversity in a sustainable way, researchers have begun to focus their research on renewable sources, under-explored, but that have the prospect as the reservoir of new structures of bioactive metabolites, namely fungal endophytes. Fungal endophytes grow within the internal tissue $s$ of the plant, without causing pathogenic symptoms and to have succeeded in producing secondary metabolites with diverse chemical structures and pharmacological activities such as antibacterial, antifungal, insecticide, antioxidant, anti hyperlipidaemia, cytotoxic and anticancer. However, under conventional laboratory conditions, a plethora of secondary metabolites encoded in fungal endophytes were not produced presumably because the genes responsible for the secondary metabolites biosynthetic are not transcribed (remain silent). Several methods have been explored to activate these silent genes, including optimization parameters of fermentation, co-culture techniques, precursors/ plant extracts feeding, the addition of epigenetic modifiers such as DNA methyltransferase (DNMT) or histone deacetylase (HDAC) inhibitors, and genetic manipulation of biosynthetic and regulatory genes. The approaches in culture techniques are expected to bridge the debate in drug discovery and natural material production from endophytic fungi.

Keywords: fungal endophytes, pharmacological activities, activating silent gene
\end{abstract}

\section{Intisari}

Eksplorasi besar-besaran tanaman obat sebagai sumber bahan baku obat dan tingginya permintaan akan obat tradisional di pasaran telah menimbulkan permasalahan dalam biodiversitas dan ancaman bagi spesies tanaman. Peneliti bahan alam telah mulai memfokuskan penelitannya pada sumber terbarukan yang belum tereksplorasi namun memiliki prospek sebagai penyedia keanekaragaman struktur kimia, yaitu jamur endofit. Jamur endofit hidup di dalam jaringan tanaman tanpa menimbulkan simptom patogenik dan telah dilaporkan menghasilkan metabolit sekunder dengan struktur kimia yang beragam dengan aktivitas farmakologi yang luas seperti antibakteri, antijamur, insektisida, antioksidan, antihiperlipidemia, sitotoksik dan antikanker yang sangat potensial untuk dikembangkan dalam industri farmasi. Dalam pengembangannya, pemanfaatan jamur endofit memiliki beberapa kendala, utamanya dalam teknik kultur / fermentasi dalam rangka mengaktifkan gen penyandi biosintesis metabolit sekunder yang relatif inaktif selama kultur. Metode untuk mengaktifkan gen diam (silent gene) dapat dilakukan dengan beberapa cara yaitu: optimasi parameter fermentasi, teknik ko-kultur, penambahan prekursor atau zat antara ke dalam media kultur, penambahan modifikator epigenetik seperti inhibitor DNA methyltransferase (DNMT) dan atau inhibitor histone deacetylase (HDAC), dan manipulasi genetik. Pendekatan dalam teknik kultur jamur endofit diharapkan dapat menjembatani permasalahan dalam penemuan obat dan produksi bahan alam dari jamur endofit.

Kata kunci: jamur endofit, aktivitas farmakologi, aktivasi gen diam 


\section{Pengantar}

Bahan alam (natural products) merupakan kunci utama dalam pengembangan obat terutama sebagai sumber senyawa penuntun. Bahan alam menjadi sumber utama penyedia keanekaragaman struktur senyawa kimia dibandingkan pengembangan struktur melalui kimia kombinatorial (Newman \& Cragg, 2016). Dalam tiga dekade terakhir eksplorasi besar-besaran untuk menemukan senyawa baru bahan baku obat dari tanaman telah dilakukan namun proses uji farmakologi yang dilakukan baru mencapai sekitar 6\% dari total species tanaman yang ada (24 ribu dari 391 ribu species), dan hanya 15\% diantaranya yang dilakukan uji fitokimia (Newman \& Cragg, 2012).

Proses penemuan senyawa penuntun dengan metode konvensional merupakan proses yang panjang, membutuhkan biaya yang relatif mahal, dan membutuhkan banyak pelarut dan bahan kering tanaman sebagai bahan baku. Selain itu, proses tersebut dilakukan dengan teknik ekstraksi dan isolasi yang umum yang seringkali memperoleh senyawa yang pernah ditemukan sebelumnya (re-discovery) dengan aktivitas biologi yang tidak konsisten. Proses penemuan senyawa dari bahan alam telah mengalami perubahan perspektif dengan lebih memperhatikan biodiversitas sebagai dampak dari pemanasan global. Peneliti bahan alam telah mulai memfokuskan penelitannya pada sumber terbarukan yang belum tereksplorasi namun memiliki prospek sebagai penyedia keanekaragaman struktur kimia, yaitu jamur endofit. Jamur endofit tumbuh di dalam jaringan tanaman dan menyebabkan infeksi yang tidak terlihat dan tidak bergejala. Jamur endofit semakin dikenal sebagai produsen dalam biosintesis produk alami sejak penemuan Taxol yang berhasil disintesis oleh jamur Taxomyces andreana yang diisolasi dari batang Taxus brevifolia (Stierle et al., 1993; Y. Yang et al., 2014). Jamur ini telah terbukti sangat potensial untuk sintesis de novo dari berbagai metabolit bioaktif yang dapat secara langsung atau tidak langsung digunakan sebagai agen terapi terhadap berbagai penyakit (Kusari et al., 2012; Strobel, 2003). Riset tentang jamur endofit telah sangat meningkat jumlahnya dalam dua dekade terakhir. Berdasarkan data dari PubMed dari tahun 1964-2018, terdapat 4047 publikasi dengan kata kunci "fungal endophytes". Banyaknya riset per tahun yang memfokuskan penelitiannya pada jamur endofit dapat dilihat pada Gambar 1 berikut. 


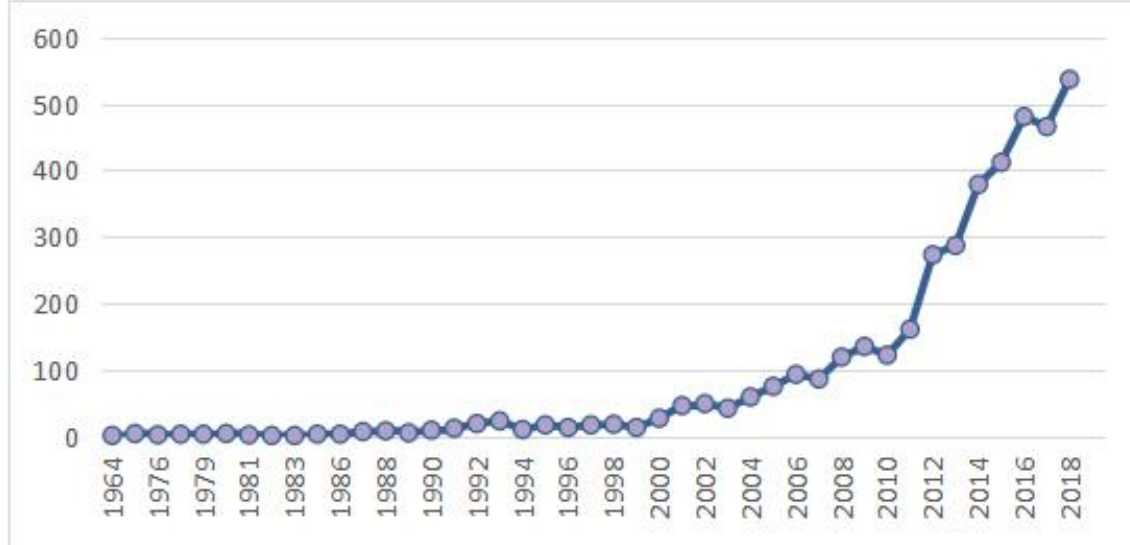

Gambar 1. Jumlah publikasi dengan topik jamur endofit (Grafik diolah dari data yang diperoleh dari publikasi di PubMed dengan kata kunci "fungal endophytes" dari tahun 1964 - 2018)

\section{Hutan Indonesia sebagai hotspot jamur endofit}

Jamur endofit dapat ditemukan pada semua tanaman mulai dari daerah Arktik sampai daerah Tropis, dengan famili terbesar Actinomycetes, Dothideomycetes, Sordariomycetes, Pezizomycetes, Leotiomycetes dan Eurotiomycetes (Arnold, 2007; Higginbotham et al., 2013). Daun tanaman di daerah Tropis terkolonisasi 100\% oleh jamur endofit sementara di daerah Arktik hanya 20\%. Bahkan, satu tanaman di daerah Tropis bisa dikolonisasi 30-40 jenis jamur endofit (Herre et al., 2009). Hal ini menunjukkan potensi tanaman di daerah tropis sebagai sumber jamur endofit. Sebagai salah satu contoh adalah kawasan hutan baku Indonesia yang tumbuh di sepanjang garis pantai Indonesia sepanjang $95.000 \mathrm{~km}$ (23 persen dari semua ekosistem bakau di dunia)(Giri et al, 2011; von Rintelen et al., 2017) merupakan sumber dari lebih dari 200 spesies jamur endofit (M. Y. Li et al., 2009) dengan serangkaian bioaktivitas luar biasa seperti sitotoksik dan antiinfeksi serta aktivitas khusus sebagai penghambat protein kinase, $\alpha$ - glukosidase, asetilkolinesterase dan tirosinase (Debbab et al., 2013). Sayangnya, penelitian pemanfaatan jamur endofit masih sangat minim dan terbatas pada penggunaannya sebagai agen biokontrol dalam bidang pertanian dan agroindustri (Ministry of Environment and Forestry of Indonesia, 2014). Pemanfaatan jamur endofit untuk pengembangan obat masih sangat terbatas baik dari segi jenis penelitian dan sumber dana penelitian (Kementerian Riset Teknologi dan Pendidikan Tinggi, 2017) sehingga diperlukan langkah strategis dan integratif dalam pengembangannya. 


\section{Aktivitas farmakologi dari jamur endofit}

Jamur endofit telah banyak diaplikasikan dalam bidang pertanian sebagai biopestisida atau pengatur pertumbuhan tanaman (Butt TM, Jackson C, 2001; Gao et al., 2010; S. N. Kumar et al., 2014) , dalam bidang industri sebagai sumber enzim dan katalis (Corrêa et al., 2014; Toghueo \& Boyom, 2020), dan dalam bidang teknik lingkungan digunakan untuk fitoremediasi atau pengontrol polusi (Rozpadek et al., 2017; C. Wang et al., 2014). Di dalam bidang kesehatan, jamur endofit telah banyak diteliti dan dilaporkan memiliki aktivitas farmakologi yang cukup luas. Senyawa aktif beberapa jamur endofit telah berhasil diisolasi dan menunjukkan struktur kimia yang bervariasi mulai dari benzopiran, poliketida, terpenoid, senyawa fenolik, alkaloid, peptida dan peptida siklik, serta diketopiperazin (Barakat et al., 2018; Mousa \& Raizada, 2013). Contoh metabolit beserta jamur penghasil dan aktivitas farmakologinya dapat dilihat pada Tabel 1 dan contoh struktur metabolit sekunder dari jamur endofit dapat dilihat pada Gambar 2

Tabel 1. Metabolit dan aktivitas farmakologi jamur endofit

\begin{tabular}{|c|c|c|c|c|}
\hline Metabolit & $\begin{array}{c}\text { Golongan } \\
\text { senyawa }\end{array}$ & Aktivitas & Endofit & Referensi \\
\hline Aureonitol & $\begin{array}{l}\text { Aromatik } \\
\text { sederhana }\end{array}$ & Antibakteri & $\begin{array}{l}\text { Chaetomium globosum } \\
\text { dari tanaman tomat }\end{array}$ & Kurt et al., 2016 \\
\hline $\begin{array}{l}\text { Biscogniazaphilone A } \\
\text { Biscogniazaphilone B }\end{array}$ & $\begin{array}{l}\text { Azapilon 2- } \\
\text { benzopiran }\end{array}$ & Antimikobakterium & $\begin{array}{l}\text { Biscogniauxia } \\
\text { formosana BCRC } 33718 \\
\text { dari Cinnamomum sp. }\end{array}$ & Cheng et al., 2012 \\
\hline Beauvericin & Depsipeptidaa & $\begin{array}{l}\text { Antibakteri terhadap } \\
\text { MRSA dan B. subtilis }\end{array}$ & $\begin{array}{l}\text { F. oxysporum dari } \\
\text { tanaman C. kanehirae }\end{array}$ & $\begin{array}{l}\text { Q.-X. Wang et al., } \\
2011\end{array}$ \\
\hline $\begin{array}{l}\text { Cochlioquinone A } \\
\text { Isocochlioquinone A }\end{array}$ & Meroterpenoid & Antileishmania & $\begin{array}{l}\text { Cochliobolus sativus dari } \\
\text { Vernonia polyanthes }\end{array}$ & $\begin{array}{l}\text { do Nascimento } \\
\text { et al., } 2015\end{array}$ \\
\hline Guanacastepene & Diterpenoid & $\begin{array}{l}\text { Antibakteri terhadap } \\
\text { MRSA dan } \\
\text { Enterococcus faecium } \\
\text { yang resisten } \\
\text { vancomycin }\end{array}$ & $\begin{array}{l}\text { Jamur dari tanaman } \\
\text { Daphnopsis americana }\end{array}$ & Brady et al., 2001 \\
\hline
\end{tabular}




\begin{tabular}{|c|c|c|c|c|}
\hline Metabolit & $\begin{array}{c}\text { Golongan } \\
\text { senyawa }\end{array}$ & Aktivitas & Endofit & Referensi \\
\hline Phomopsichalasin & Sitokalasin & $\begin{array}{l}\text { Antibakteri terhadap } \\
\text { B. subtilis, S. aureus, } \\
\text { dan Salmonella } \\
\text { gallinarum (patogen } \\
\text { pada unggas) dan } \\
\text { antijamur terhadap } \\
\text { Candida tropicalis }\end{array}$ & $\begin{array}{l}\text { Phomopsis sp. yang } \\
\text { diisolasi dari tanaman } \\
\text { Salix gracilostyla }\end{array}$ & $\begin{array}{c}\text { Sunil K. } \\
\text { Deshmukh } \text { et al., } \\
2018 \\
\text { Sunil Kumar } \\
\text { Deshmukh } \text { et al., } \\
2014\end{array}$ \\
\hline Sordaricin & Diterpenoid & $\begin{array}{l}\text { Antijamur terhadap } \\
\text { C. albicans }\end{array}$ & $\begin{array}{l}\text { Xylaria sp. yang diisolasi } \\
\text { dari tanaman Garcinia } \\
\text { dulcis }\end{array}$ & $\begin{array}{c}\text { Mousa \& Raizada, } \\
2013\end{array}$ \\
\hline $\begin{array}{l}1 \alpha-10 \alpha \text {-Epoxy- } 7 \alpha- \\
\text { hydroxyeremophil-11-en- } \\
12,8-\beta \text {-olide }\end{array}$ & Sesquiterpenoid & $\begin{array}{l}\text { Antimalaria terhadap } \\
\text { Plasmodium } \\
\text { falciparum }\end{array}$ & $\begin{array}{l}\text { Xylaria sp. BCC } 21097, \\
\text { yang diisolasi dari } \\
\text { Licuala spinosa }\end{array}$ & Isaka et al., 2010 \\
\hline $\begin{array}{l}\text { monocerin dan } 11- \\
\text { hydroxymonocerin }\end{array}$ & Poliketida & $\begin{array}{l}\text { Antimalaria terhadap } \\
\text { P. falciparum }\end{array}$ & $\begin{array}{l}\text { Jamur yang diambil dari } \\
\text { Exserohilum rostratum }\end{array}$ & $\begin{array}{l}\text { Sappapan et al., } \\
2008\end{array}$ \\
\hline $\begin{array}{l}\text { Palmarumycin } C P 17 \\
\text { Palmarumycin CP18 }\end{array}$ & Spirobisnaftalen & Antileishmania & $\begin{array}{l}\text { Edenia sp. dari tanaman } \\
\text { Petrea volubilis }\end{array}$ & $\begin{array}{l}\text { Martínez-luis } \\
\text { et al., } 2011\end{array}$ \\
\hline Cercosporin & Poliketida & Antileishmania & $\begin{array}{l}\text { Mycosphaerella sp. nov. } \\
\text { strain F2140 dari } \\
\text { Psychotria horizontalis }\end{array}$ & $\begin{array}{l}\text { Moreno et al., } \\
\quad 2011\end{array}$ \\
\hline $\begin{array}{l}\text { Pestacin } \\
\text { Isopestacin }\end{array}$ & Isobenzofuran & Antioxidant & $\begin{array}{l}\text { P. microspora dari } \\
\text { T. morobensis }\end{array}$ & $\begin{array}{c}\text { Kouipou \& Boyom, } \\
2019 \\
\text { Strobel \& Daisy, } \\
2003\end{array}$ \\
\hline Tauranin & Sesquiterpenoid & $\begin{array}{l}\text { Sitotoksik pada sel } \\
\text { NCI-H460 (non small } \\
\text { cell lung cancer), MCF- } \\
7 \text { (sel kanker } \\
\text { payudara), SF-268 } \\
\text { (glioma), PC-3M (sel } \\
\text { kanker prostat } \\
\text { metastatik), dan MIA } \\
\text { Pa Ca-2 }\end{array}$ & $\begin{array}{l}\text { Phyllosticta spinarum } \\
\text { yang diisolasi dari } \\
\text { tanaman Platycladus } \\
\text { orientalis }\end{array}$ & Aly et al., 2011 \\
\hline Altersolanol & Antranoid & Antiangiogenesis & $\begin{array}{l}\text { Alternaria sp. dari } \\
\text { tanaman Erythrina } \\
\text { variegata }\end{array}$ & $\begin{array}{l}\text { Pompeng et al., } \\
2013\end{array}$ \\
\hline Guignasulfide & Benzofenon & $\begin{array}{l}\text { Sitotoksik terhadap } \\
\text { sel kanker manusia } \\
\text { HepG2 }\end{array}$ & $\begin{array}{l}\text { Guignardia sp. IFB-E028 } \\
\text { yang diambil dari } \\
\text { tanaman Hopea } \\
\text { hainanensis }\end{array}$ & $\begin{array}{l}\text { F. W. Wang et al., } \\
2010\end{array}$ \\
\hline
\end{tabular}


57 | Asih, T. /Jurnal Ilmiah Farmasi 16(1) Januari-Juli 2020, 52-73

\begin{tabular}{|c|c|c|c|c|}
\hline Metabolit & $\begin{array}{l}\text { Golongan } \\
\text { senyawa }\end{array}$ & Aktivitas & Endofit & Referensi \\
\hline Diaporthesin $C$ & Poliketida & $\begin{array}{l}\text { Penghambatan } \\
\text { trigliserida pada } \\
\text { sel steatotic } L-02\end{array}$ & Diaporthe sp. JC-J7 & Hu et al., 2018 \\
\hline Cycloepoxylactone & $\begin{array}{l}\text { Monokarbosiklik } \\
\text { poliketida }\end{array}$ & Antijamur, antibakteri & $\begin{array}{l}\text { Phomopsis sp dari } \\
\text { Laurus azorica }\end{array}$ & $\begin{array}{l}\text { Hussain et al., } \\
\quad 2009\end{array}$ \\
\hline Cryptocandin & Lipopeptida & Antijamur & $\begin{array}{l}\text { Cryptosporiopsis cf. } \\
\text { quercina dari } \\
\text { Tripterigium wilfordii }\end{array}$ & Strobel et al., 1999 \\
\hline $\begin{array}{l}\text { Deacetyl- } \\
\text { mycoepoxydiene }\end{array}$ & $\begin{array}{l}\text { Monokarbosiklik } \\
\text { poliketida }\end{array}$ & $\begin{array}{l}\text { Antikanker pada sel } \\
\text { MCF }\end{array}$ & $\begin{array}{l}\text { Phomopsis sp. dari } \\
\text { tanaman bakau }\end{array}$ & Zhu et al., 2015 \\
\hline $\begin{array}{l}\text { 7-desmethyl fusarin } C \text { - } \\
\text { derivates }\end{array}$ & Alkaloid pirolidin & $\begin{array}{l}\text { Antibakteri terhadap } \\
\text { E. coli }\end{array}$ & $\begin{array}{l}\text { Fusarium solani JK10 } \\
\text { yang diambil dari } \\
\text { Chlorophora regia }\end{array}$ & $\begin{array}{c}\text { Kyekyeku et al., } \\
2017\end{array}$ \\
\hline Epichlicin & Peptida siklik & Antijamur & $\begin{array}{l}\text { Ephichloe typina dari } \\
\text { Phleum pretense }\end{array}$ & Seto et al., 2007 \\
\hline Pestalofone F & $\begin{array}{l}\text { Asam amino dan } \\
\text { peptida }\end{array}$ & $\begin{array}{l}\text { Sitotoksik terhadap } \\
\text { sel HeLa dan MCF-7 } \\
\text { cells }\end{array}$ & Pestalotiopsis fici & $\begin{array}{c}\text { S. Kumar \& } \\
\text { Kaushik, } 2012\end{array}$ \\
\hline Phomone D & Poliketida & Antikanker & Phoma sp. YN02-P-3 & S. J. Li et al., 2018 \\
\hline Pycnophorin & Meroterpenoid & $\begin{array}{l}\text { Antibakteri terhadap } \\
\text { S. aureus dan } B \text {. } \\
\text { subtilis }\end{array}$ & $\begin{array}{l}\text { Botryosphaeria } \\
\text { dothidea, diisolasi dari } \\
\text { Melia azedarach }\end{array}$ & Xiao et al., 2014 \\
\hline Paclitaxel & Diterpenoid & Antikanker & Taxomyces andreanae & Heinig et al., 2013 \\
\hline Torreyanic acid & $\begin{array}{l}\text { Alifatik- } \\
\text { Polisikloheteroali } \\
\text { siklik }\end{array}$ & Sitotoksik & $\begin{array}{l}\text { Pestalotiopsis } \\
\text { microspora }\end{array}$ & Kaul et al., 2012 \\
\hline 10-Hydroxycamptothecin & $\begin{array}{l}\text { Alkaloid } \\
\text { kamptotesin }\end{array}$ & Antikanker & $\begin{array}{l}\text { Fusarium solani } \\
\text { dari Camptotheca } \\
\text { acuminata }\end{array}$ & Pu et al., 2013 \\
\hline
\end{tabular}




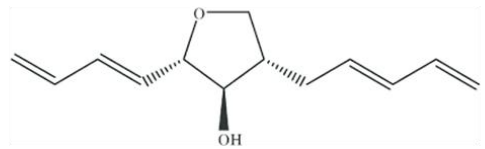

Aureonitol

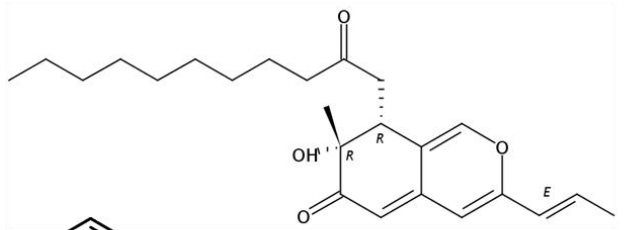

Beauvericin

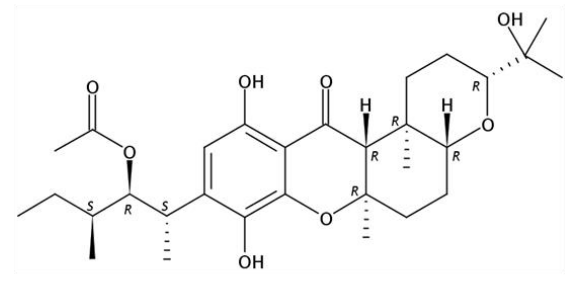

Isocochlioquinone $\mathrm{A}$

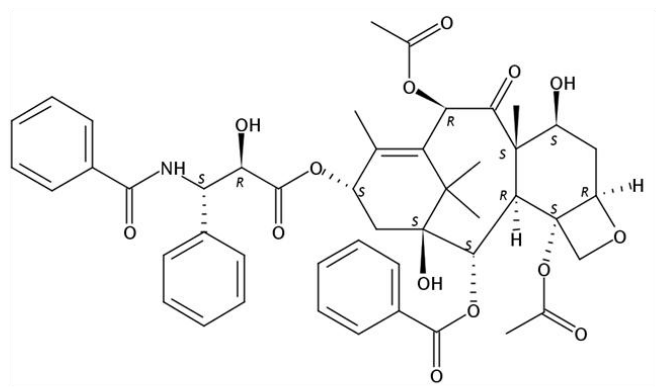

Paclitaxel

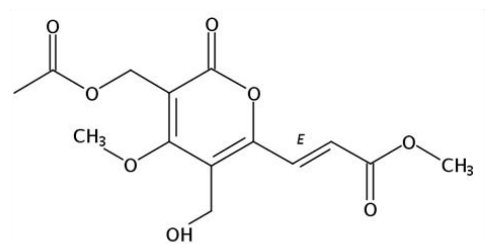

Phomone D

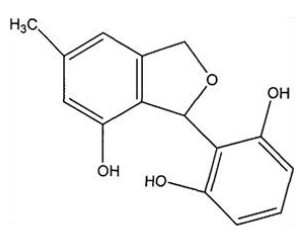

Pestacin

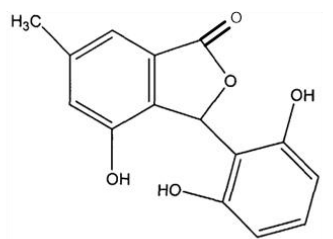

Isopestacin

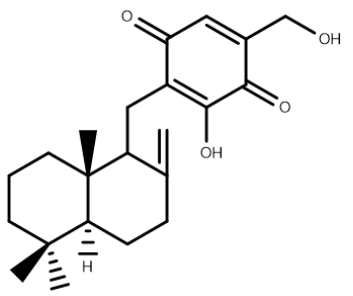

Tauranin

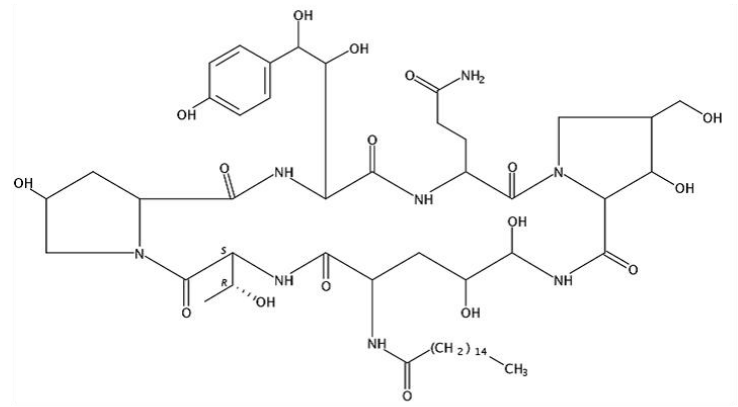

Cryptocandin

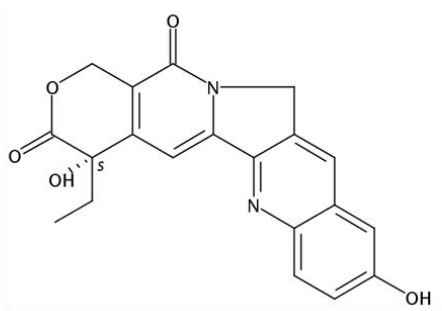

10-Hydroxycamptothecin<smiles>COc1cc(O)c2c(c1)C(=O)C1=C(C2=O)[C@H](O)[C@H](O)[C@](C)(O)[C@H]1O</smiles>

Artesolanol A

Gambar 2. Beberapa contoh metabolit sekunder dari jamur endofit 


\subsection{Antimikroba}

Jamur endofit melindungi tanaman terhadap berbagai macam patogen seperti bakteri, jamur, dan serangga yang memungkinkan sifat antimikroba tersebut umum ditemukan pada beberapa genera jamur seperti Aspergillus, Alternaria, Colletotrichum, Fusarium, Penicillium, dan Pestalotiopsis (Casella et al., 2013; Gupta et al., 2020; Martín-Rodríguez et al., 2014; Selim et al., 2012). Beberapa jenis jamur yang potensial misalnya Fusarium tricinctum yang diisolasi dari Rhododendron tomentosum, menghasilkan senyawa antibakteri dan antijamur terhadap Staphylococcus carnosus dan Candida albicans serta C. utilis. Sementara itu ekstrak heksan jamur Colletotrichum gloeosporioides yang diisolasi dari tanaman obat Vitex negundo memiliki aktivitas antibakteri terhadap bakteri $S$. aureus yang resisten terhadap methicillin, penicillin dan vancomycin (Arivudainambi et al., 2011). Jamur F. oxysporum dari tanaman C. kanehirae memproduksi senyawa beauvericin yang memiliki aktivitas kuat terhadap MRSA dan Bacillus subtilis dengan nilai MIC $3.125 \mu \mathrm{g} / \mathrm{mL}$ (Q.-X. Wang et al., 2011). Jamur dari tanaman Meliotus dentatus memproduksi senyawa poliketida yaitu cis-4-acetoxyoxymellein dan 8-deoxy-6-hydroxy-cis-4-acetoxyoxymellein yang aktif terhadap Escherichia coli dan Bacillus megaterium. Kedua poliketida tersebut juga aktif terhadap jamur Microbotryum violaceum dan Botrytis cinerea (Hussain et al., 2015).

Guanacastepene, suatu diterpenoid yang diproduksi oleh jamur dari tanaman Daphnopsis americana memiliki aktivitas antibakteri terhadap MRSA dan Enterococcus faecium yang resisten vancomycin dengan mekanisme perusakan membran bakteri (Brady et al., 2001). Phomopsichalasin dari jamur Phomopsis sp. yang diisolasi dari tanaman Salix gracilostyla memiliki aktivitas anti bakteri terhadap B. subtilis, S. aureus, dan Salmonella gallinarum (patogen pada unggas) dan antijamur terhadap Candida tropicalis (Sunil K. Deshmukh et al., 2018; Sunil Kumar Deshmukh et al., 2014). Sordaricin yang diisolasi dari Xylaria sp. dari tanaman Garcinia dulcis menunjukkan aktivitas antijamur moderat terhadap C. albicans. Sordarin sebelumnya terbukti menghambat sintesis protein jamur dengan mekanisme mengikat secara selektif dan menghambat faktor pemanjangan 2 (EF-2) yang mengkatalisasi translokasi ribosom selama proses translasi (Justice et al., 1998; Mousa \& Raizada, 2013)

\subsection{Antiparasit}

Jamur Xylaria sp. BCC 21097, yang diisolasi dari Licuala spinosa menghasilkan senyawa $1 \alpha-$ $10 \alpha$-Epoxy-7 $\alpha$-hydroxyeremophil-11-en-12,8- $\beta$-olide yang aktif terhadap Plasmodium falciparum dengan mekanisme terkait dengan struktur epoksid dari senyawa tersebut (Isaka et al., 2010). Beberapa metabolit dari jamur endofit juga menunjukkan aktivitas terhadap P. falciparum (K1, 
multidrug-resistant strain) seperti monocerin dan 11-hydroxymonocerin yang diisolasi dari Exserohilum rostratum dengan $\mathrm{IC}_{50}$ berturut-turut 0.68 dan $7.70 \mu \mathrm{M}$ dan metabolit turunan benzoquinone dan xylariaquinone A dari Xylaria sp. dengan $\mathrm{IC}_{50} 1.84$ dan $6.68 \mu \mathrm{M}$, dan Phomoxanthones A dan B, dari jamur Phomopsis sp. BCC 1323 (Sappapan et al., 2008; Tansuwan et al., 2007).

Palmarumycin CP17 dan palmarumycin CP18 yang diisolasi dari Edenia sp. dari tanaman Petrea volubilis mampu menghambat amastigot dari Leishmania donovani, penyebab leishmaniasis dengan $\mathrm{EC}_{50}$ berturut-turut 1.34 and $0.62 \mu \mathrm{M}$, (kontrol positif amphoterycin $\mathrm{B}=\mathrm{EC}_{50} 0.09 \mu \mathrm{M}$ ) dan memiliki aktivitas toksisitas rendah terhadap sel Vero (Martínez-luis et al., 2011). Cercosporin dan metabolit analog dari Mycosphaerella sp. nov. strain F2140 yang diambil dari tanaman Psychotria horizontalis juga menunjukkan aktivitas penghambatan pada L. donovani ( $\mathrm{IC}_{50} 0.46$ dan $0.64 \mu \mathrm{M}$ ), Tripanosoma cruzi (IC 501.08 and $0.78 \mu \mathrm{M}$ ) dan P. falciparum ( $\mathrm{IC}_{50} 1.03$ dan $2.99 \mu \mathrm{M}$ ) (Moreno et al., 2011).

\subsection{Antioksidan}

Ekstrak dari jamur endofit juga dilaporkan memiliki aktivitas sebagai antioksidan berdasarkan uji antioksidan dengan metode DPPH seperti jamur Aspergillus awamori DT11 yang diisolasi dari tanaman stroberi. Senyawa golongan flavonoid dan terpenoid yang terkandung dalam ekstrak memungkinkan efek antioksidan tersebut (Hipol et al., 2014). Selain itu, ekstrak dari jamur Aspergillus sp.JPY1 dan Phoma sp. dari tanaman S. oleoides juga memiliki aktivitas antioksidan yang tinggi dan tidak menunjukkan toksisitas pada hewan uji sampai dosis 1000mg/kgBB (Dhankhar et al., 2012).

Huang et al., (2007) telah meneliti 292 jamur endofit dari 29 tanaman obat dan menemukan aktivitas antioksidan yang bervariasi dari jamur endofit. Aktivitas terbesar dimiliki oleh jamur AcapF3 dari Artemisia capillaris dengan aktivitas of $526.93 \mu \mathrm{mol}$ trolox/100 ml kultur dan jamur TwL3 dari tanaman T. wightianus dengan aktivitas antioksidan (298.35 $\mu$ mol/100 ml kultur. Analisis terbaru dari Gupta et al., (2020) menyatakan bahwa senyawa seperti Pestacin, Isopestacin, Rutin, Corynesidones A dan B, Borneol, Lapachol, Coumarin, p-Tyrosol dari jamur endofit memiliki aktivitas antioksidan yang potensial.

\subsection{Antikanker}

Banyak jamur endofit yang memiliki aktivitas sitotoksik kuat terhadap beberapa jenis sel kanker sehingga potensial dikembangkan sebagai senyawa antikanker. Sebagai contoh, senyawa tauranin dari jamur Phyllosticta spinarum yang diisolasi dari tanaman Platycladus orientalis 
memiliki aktivitas sitotoksik dengan $\mathrm{EC}_{50}$ berturut-turut 4.3, 1.5, 1.8, 3.5, and $2.8 \mu \mathrm{M}$ terhadap sel NCI-H460 (non small cell lung cancer), MCF-7 (sel kanker payudara), SF-268 (glioma), PC-3M (sel kanker prostat metastatik), dan MIA Pa Ca-2 (sel karsinoma pankreas), dibandingkan dengan doxorubicin sebagai kontrol positif dengan $\mathrm{EC}_{50}$ berturut-turut $0.01,0.07,0.04$, dan $1.11 \mu \mathrm{M}$. Mekanisme dari tauranin adalah dengan menginduksi apoptosis pada sel kanker (Aly et al., 2011). Selain itu, altersolanol yang diproduksi oleh Alternaria sp. dari tanaman Erythrina variegata dilaporkan memiliki aktivitas antiangiogenesis (penghambatan pembentukan pembuluh darah baru pada kanker). Pada model sel endotelial vena umbelikal manusia, altersolanol mampu menghambat proliferasi, pembentukan pembuluh darah, dan migrasi dari sel endotelial (Pompeng et al., 2013). Sementara itu, senyawa guignasulfide dari jamur Guignardia sp. IFB-E028 yang diambil dari tanaman Hopea hainanensis memiliki aktivitas sitotoksik terhadap sel kanker manusia HepG2 dengan $\mathrm{EC}_{50}$ 5.2 $\pm 0.4 \mu \mathrm{M}$ (F. W. Wang et al., 2010).

\subsection{Antituberkulosis}

Sebanyak 1,5 juta orang meninggal karena tuberkulosis (TB) pada tahun 2018 (termasuk 251.000 orang dengan HIV). Di seluruh dunia, TB adalah salah satu dari 10 penyebab utama kematian dan penyebab utama dari satu agen infeksius (di atas HIV / AIDS) (World Health Organization, 2020). Jamur endofit telah dilaporkan memiliki aktivitas terhadap Mycobacterium tuberculosis. Sebagai contoh, senyawa diaporthein B dari kultur jamur Diaporthe sp. BCC 6140 dan Phomoenamide dari jamur Phomopsis sp. dari tanaman Garcinia dulcis memiliki aktivitas penghambatan pertumbuhan bakteri TB dengan metode kolorimetri menggunakan Alamar Blue (Dettrakul et al., 2003; Rukachaisirikul et al., 2008). Contoh lain, jamur Chaetomium globosum menghasilkan alkaloid piperazine yang aktif terhadap Mycobacterium tuberculosis H37Ra dengan konsentrasi hambat minimum (MIC) sebesar 169.92 mM (Martins \& Carvalho, 2007) dan 3nitropropionic acid berhasil diisolasi dari Phomopsis longicolla dari tanaman Trichilia elegans yang aktif terhadap bakteri TB (Flores et al., 2013). Senyawa Chaetoglobosin A dan chaetoglobosin B dari Asperillus fumigatus juga aktif terhadap Mycobacterium tuberculosis H37Ra selain aktif pada bakteri S. aureus dan MRSA (Flewelling et al., 2015).

\subsection{Antihyperlipidemia}

Jamur Diaporthe arengae yang diisolasi dari Terminalia arjuna mengandung senyawa fenolik yang memiliki aktivitas anti-hiperkolesterol dengan penghambatan peroksidasi lipid secara in vitro dan mampu menurunkan kolesterol total dan LDL kolesterol pada hewan uji (Patil et al., 2017). 
Selain itu, senyawa diaporthesin $C$ yang diisolasi dari fermentasi Diaporthe sp. JC-J7 menunjukkan penghambatan trigliserida pada sel steatotic L-02 (Hu et al., 2018). Hal ini merupakan bukti potensi jamur endofit untuk dapat dikembangkan sebagai sumber bahan baku obat.

\section{Tantangan dalam pengembangan jamur endofit}

\subsection{Seleksi tanaman sebagai sumber jamur endofit}

Mempertimbangkan besarnya jumlah dan biodiversitas tanaman, strategi yang tepat harus digunakan untuk mempersempit pencarian endofit yang potensial sebagai sumber senyawa obat. Beberapa hipotesis yang mengatur strategi pemilihan tanaman ini telah dikemukakan oleh Strobel dan Daisy (2003) yaitu: (i) Tanaman yang hidup di ekosistem khas, dengan kondisi biologi yang tidak biasa dan memiliki strategi unik untuk bertahan hidup, misalnya tanaman bakau (Apurillo et al., 2019; Calcul et al., 2013; Osorio et al., 2017); (ii) Tumbuhan yang memiliki sejarah etnobotani (digunakan oleh masyarakat secara turun-temurun) yang terkait dengan penggunaan sebagai obat (etnomedisin) misalnya Melia azadirachta (mimba) atau Centella asiatica (pegagan) dan Piper betle (sirih) yang penggunaanya sangat luas di masyarakat untuk pengobatan (Alam et al., 2015; James \& Dubery, 2011; Srinivasan et al., 2016; Xiao et al., 2014); (iii) Tumbuhan yang endemik, yang memiliki umur panjang yang tidak biasa, cenderung untuk berkoloni dengan endofit dibandingkan tanaman lain, misalnya Taxus sp. penghasil obat kanker paclitaxel (Stierle et al., 1993); (iv) Tanaman yang tumbuh di daerah dengan keanekaragaman hayati yang besar seperti tanaman yang hidup di hutan Indonesia atau hutan Amerika Selatan (Ferreira et al., 2015; Sieber, 2007).

\subsection{Kondisi kultur jamur endofit di laboratorium}

Gen penyandi biosintesis metabolit sekunder pada jamur terletak pada segmen gen sepanjang lebih dari $10 \mathrm{~kb}$ dan tersusun dalam suatu kluster atau multidomain (Reen et al., 2015). Pada kondisi kultur laboratorium, jamur ditumbuhkan pada cawan petri secara aksenik (monokultur) sehingga "komunikasi mikrobial" yang awalnya tersedia sebagai interaksi antara jamur endofit dengan tanaman inang atau mikrobial lain yang tumbuh pada tanaman tersebut dan sebagai sinyal pengkode sintesis metabolit sekunder menjadi hilang. Dengan tidak adanya rangsangan ini mengakibatkan produksi metabolit sekunder hanya sedikit. Untuk meniru komunikasi mikrobia sehingga produksi metabolit sekunder pada isolat fungi bisa meningkat, dapat dilakukan proses penambahan ekstrak tanaman pada kultur jamur atau dengan mengkulturkan jamur endofit dengan jamur lain. Selain komunikasi mikrobial, rangsang berbeda selama kultur seperti perbedaan 
pada komposisi media, $\mathrm{pH}$, suhu, kondisi osmotik juga dapat mempengaruhi pertumbuhan dan jenis metabolit sekunder yang dihasilkan oleh jamur (Nützmann et al., 2012). Sebagian besar spesies jamur tumbuh subur dalam kondisi hangat, bergula, asam, dan aerobik. Sedangkan untuk suhu, kisaran untuk pertumbuhan jamur cukup luas, tetapi secara umum sebagian besar spesies tumbuh sangat baik sekitar $25^{\circ} \mathrm{C}$. Parameter fisik lain yang mempengaruhi fisiologi jamur termasuk radiasi (cahaya atau UV dapat menimbulkan diferensiasi miselia dan sporulasi pada beberapa jamur yang menghasilkan spora di udara), aerasi, dan gaya sentrifugal (misal pada kultur kinetik) (Kavanagh, 2005). Faktor-faktor tersebut dapat dimodifikasi dengan harapan akan mempengaruhi pertumbuhan dan fisiologi jamur dan produksi metabolit.

\subsection{Metode mengaktifkan jalur kriptik pada jamur endofit}

Beberapa metode telah dieksplorasi untuk mengaktifkan jalur biosintetik diam yang juga disebut "jalur kriptik". Menariknya, pendekatan ini tidak hanya mengarah pada penemuan metabolit sekunder baru, tetapi juga pada akumulasi senyawa yang sudah diproduksi sebelumnya Optimalisasi parameter yang mempengaruhi produksi metabolit dari strain jamur endofit yang potensial dapat dilakukan dengan menggunakan berbagai media kultur dan kondisi kultur yang berbeda. Bode et al. (2002) mengenalkan istilah "One Strain Many Compounds" (OSMACs), untuk menggambarkan bagaimana strain jamur tunggal dapat diinduksi untuk menghasilkan banyak senyawa dengan hanya memvariasikan parameter kultur seperti mengubah pH dan mengubah komposisi nutrisi seperti mengubah kadar glukosa dan kadar asam amino (Bode et al., 2002). Berbagai jenis media komersial seperti PDA (Potato dextrose agar), atau PDB (Potato dextrose broth), MEA (Malt Extract agar), dan YMA (Yeast malt agar) atau media alami seperti media dari beras yang direbus dan media ekstrak buah cherry dengan kandungan nutrisi yang bervariasi dapat digunakan untuk melihat pertumbuhan produksi metabolit sekunder. Kondisi yang berbeda ini dapat secara dramatis mengubah profil metabolit sekunder dan bahkan menginduksi sintesis beberapa metabolit baru (Suryanarayanan et al., 2009). Penelitian menunjukkan bahwa ketika jamur ditanam pada media yang miskin nutrisi dibandingkan dengan media yang kaya nutrisi akan menghasilkan metabolit sekunder yang lebih banyak sebagai tanggapan atas rangsang "stress nutrisi" (Martínez-luis et al., 2011). Sebagai contoh, jamur endofit yang diisolasi dari tanaman di Panama yang dikulturkan pada media Czapek Dox (mengandung sukrosa, $\mathrm{NaNO}_{3}$ dan $\mathrm{K}_{2} \mathrm{HPO}_{4}$ ) memberikan aktivitas anti kanker dan antiparasit yang lebih baik dibandingkan jika ditanam pada media kaya seperti MME (Modified malt extract) yang mengandung malt, peptone, dan dextrose atau PDB yang mengandung ekstrak kentang dan dekstrosa. Keterbatasan kandungan nitrogen dan 
karbon pada media Czapek Dox menyebabkan stres pada jamur, dan transduksi sinyal stres ini menginduksi respons perlindungan berupa sintesis metabolit sekunder untuk memungkinkan bertahan hidup di media tersebut. Metode modifikasi media jamur merupakan metode yang relatif sederhana dan mudah dilakukan. Kelemahan pada metode ini adalah banyaknya modifikasi parameter pertumbuhan (seperti media, $\mathrm{pH}$, temperatur) yang harus diamati hingga diperoleh parameter pertumbuhan optimal untuk memacu produksi metabolit sekunder sehingga akan banyak ekstrak yang diperoleh dan dianalisa.

Metode kedua adalah dengan teknik ko-kultur, yaitu teknik menumbuhkan bakteri-bakteri, jamur-jamur atau bakteri-jamur pada media yang sama untuk meniru kondisi fisiologis alami pada tanaman sehingga "komunikasi mikrobial" dapat terbentuk (Netzker et al., 2015). Beberapa penelitian terbaru melaporkan bahwa teknik ko-kultur dapat meningkatkan produksi metabolit sekunder dan juga menginduksi sintesis senyawa baru yang tidak dihasilkan oleh masing-masing mikrobia jika dikulturkan secara monokultur (Bertrand, Schumpp, Bohni, Bujard, et al., 2013; Chagas et al., 2013; Serrano et al., 2017). Sebagai contoh, ko-kultur jamur Trametes versicolor dan Ganoderma applanatum menginduksi biosintesis senyawa baru N-(4-methoxyphenyl)formamide -2$O-\beta$-D-xyloside, dan N-(4-methoxyphenyl) formamide 2-O- $\beta$-D-xylobioside (Yao et al., 2016); Trichophyton rubrum dan Bionectria ochroleuca menginduksi metabolit baru 4- hydroxysulfoxy-2,2dimethylthielavin (Bertrand, Schumpp, Bohni, Monod, et al., 2013); dan ko-kultur Alternaria tenuissima dan Nigrospora sphaerica secara signifikan meningkatkan produksi poliketida termasuk senyawa antifungi stemphyperylenol (Chagas et al., 2013). Keuntungan menggunakan metode kokultur adalah jamur dapat dikulturkan pada media agar atau media cair dengan berbagai modifikasi parameter pertumbuhan dan dapat dilakukan pada bebagai ukuran petri dish mulai dari $5 \mathrm{~cm}$ sampai $15 \mathrm{~cm}$, atau menggunakan sumuran ukuran 24 atau 6 (Bertrand, Azzollini, et al., 2014). Kultur pada petri dish langsung dapat diamati apakah ada fenomena interaksi yang menarik seperti inhibisi, atau produksi metabolit berwarna yang tidak diproduksi apabila jamur dikulturkan snediri-sendiri (monokultur). Kekurangan dari metode ini adalah diperlukan analisa metabolit sekunder yang dihasilkan oleh masing-masing jamur dan metabolit sekunder yang dihasilkan ketiga jamur dikulturkan bersama. Teknik ini membutuhkan instrumen yang bisa mendeteksi adanya perubahan (baik jumlah maupun jenis) metabolit pada mono dan ko-kultur seperti HPLCMS(Bertrand, Bohni, et al., 2014).

Selanjutnya, penambahan prekursor atau zat antara dalam jalur biosintetik ke media kultur dapat juga dilakukan untuk meningkatkan metabolit sekunder yang diinginkan. Penambahan ekstrak tanaman dari tanaman inang dapat dilakukan untuk mengoptimalkan kondisi kultur karena 
kesamaan kimia yang lebih dekat dengan lingkungan inang. Sebagai contoh, penambahan ekstrak tanaman Torreya taxifolia meningkatkan produksi Taxol dalam kultur jamur Periconia sp. dan penambahan asam benzoat sebagai zat antara sintesis Taxol juga mengakibatkan peningkatan 8 kali lipat dalam produksi Taxol (J. Y. Li et al., 1998). Metode ini membutuhkan analisa metabolit sekunder yang dapat membedakan metabolit dari ekstrak yang ditambahkan dan metabolit hasil produksi jamur. Selain itu, untuk penambahan precursor diperlukan suatu studi pendahuluan mengenai biosintesis dari senyawa target agar dapat menentukan precursor yang tepat.

Metode lain yang dapat dilakukan adalah dengan menambahkan suatu modifikator epigenetik seperti inhibitor DNA methyltransferase (DNMT) dan atau inhibitor histone deacetylase (HDAC) (Lamoth et al., 2015; Triastuti et al., 2019). Penambahan inhibitor DNMT dan HDAC meningkatkan diversitas kimiawi dengan cara menginduksi jamur untuk menghasilkan senyawa baru yang tidak diproduksi pada kultur normal (González-Menéndez et al., 2016; Siless et al., 2018; Triastuti et al., 2019; X. L. Yang et al., 2014). Sebagai contoh, penambahan inhibitor HDAC yaitu suberanilohydroxamic acid (SAHA) pada media kultur endofit tanaman kecubung (Datura stramonium) mampu menginduksi biosintesis senyawa baru, asam fusarat (Chen et al., 2013) dan tiga senyawa baru cyclodepsipeptides, desmethylisaridin $E$, desmethylisaridin $C 2$, dan isaridin $F$ pada jamur Beauveria feline (Chung et al., 2013). Penambahan asam valproat dan SAHA juga mampu mengubah komposisi metabolit sekunder pada kultur jamur Botryosphaeria mamane yang diisolasi dari tanaman Bixa orellana yang dikulturkan pada media cair (Triastuti et al., 2019). Keterbatasan metode ini adalah adanya kemungkinan reaktivitas modifikator epigenetik dengan media atau terjadinya biotransformasi modifikator epigenetik oleh jamur (Allard et al., 2016; Siless et al., 2018; Triastuti et al., 2019). Diperlukan suatu teknik analisa yang dapat mendeteksi proses degradasi atau biotrasnformasi tersebut seperti dengan teknik molecular networking.

Metode terakhir yang dapat dilakukan dan merupakan metode yang paling maju adalah dengan manipulasi genetik. Profil metabolit suatu jamur dapat diubah dengan memodifikasi gen yang mengkode protein pengatur suatu ekspresi metabolit sekunder. Sebagai contoh, penghapusan gen yang ditargetkan (knockout gene) dapat digunakan untuk menghapus ekspresi dan penggantian promotor dapat digunakan untuk memodifikasi ekspresi gen yang diinginkan. Ketika promotor induksi dipilih, peneliti dapat secara reversibel mengontrol keadaan ekspresi (on atau off) dan, dalam beberapa kasus, dapat mengatur tingkat ekspresi itu sendiri (Lim et al., 2012). Teknik-teknik ini berlaku untuk jamur yang telah dipelajari dengan luas dan diketahui profil genetikanya seperti Aspergillus nidulans (Brakhage \& Schroeckh, 2011). Knockout dari gen easA dan easB yang masingmasing mengkode NRPSs (non-ribosomal peptide synthetases) dan PKS (polyketide synthases) 
mengarah pada penemuan emericellamides (Brakhage et al., 2009; Brakhage \& Schroeckh, 2011). Langkah-langkah mengaktifkan gen kriptik dapat dipilih dengna menyesuaikan kapasitas laboratorium dan jenis jamur yang diteliti.

\section{Kesimpulan}

Jamur endofit dapat menjadi calon produsen sumber senyawa bioaktif dan kimiawi yang melimpah dan dapat diandalkan untuk penggunaan pada bidang kedokteran, pertanian, dan industri. Penelusuran aktivitas farmakologi jamur endofit hendaknya mengaplikasikan teknologi yang tepat dan efisien mengingat tingkat biodiversitas tanaman dan jamur yang sangat tinggi. Penelitian jamur endofit di Indonesia harus ditingkatkan mengingat Indonesia kaya akan tanaman obat yang secara tidak langsung sebagai sumber 'hotspot' jamur endofit. Selain itu, modifikasi kultur jamur endofit dapat diterapkan untuk meningkatkan produksi metabolit sekunder dan juga untuk menginduksi penemuan senyawa baru. Ke depan, bioprospeksi jamur endofit dari tanaman obat Indonesia diharapkan dapat mengungkapkan lebih banyak potensi metabolit untuk terapi.

\section{Daftar Pustaka}

Alam, B., Majumder, R., Akter, S., \& Lee, S. H. (2015). Piper betle extracts exhibit antitumor activity by augmenting antioxidant potential. Oncology Letters, 9(2), 863. https://doi.org/10.3892/ol.2014.2738

Allard, P. M., Péresse, T., Bisson, J., Gindro, K., Marcourt, L., Pham, V. C., Roussi, F., Litaudon, M., \& Wolfender, J. L. (2016). Integration of Molecular Networking and In-Silico MS/MS Fragmentation for Natural Products Dereplication. Analytical Chemistry, 88(6), 3317-3323. https://doi.org/10.1021/acs.analchem.5b04804

Aly, A. H., Debbab, A., \& Proksch, P. (2011). Fungal endophytes: Unique plant inhabitants with great promises. Applied Microbiology and Biotechnology, 90(6), 1829-1845. https://doi.org/10.1007/s00253-011-3270-y

Apurillo, C. C. S., Cai, L., Edison, T., Cruz, E., Lamk, R., \& Vierh, F. (2019). Diversity and bioactivities of mangrove fungal endophytes from Leyte and Samar, Philippines. 12(July), 33-48.

Arivudainambi, U. S. E., Anand, T. D., Shanmugaiah, V., Karunakaran, C., \& Rajendran, A. (2011). Novel bioactive metabolites producing endophytic fungus Colletotrichum gloeosporioides against multidrug-resistant Staphylococcus aureus. FEMS Immunology and Medical Microbiology, 61(3), 340-345. https://doi.org/10.1111/j.1574-695X.2011.00780.x

Arnold, A. E. (2007). Understanding the diversity of foliar endophytic fungi: progress, challenges, and frontiers. Fungal Biology Reviews, 21(2-3), 51-66. https://doi.org/10.1016/j.fbr.2007.05.003

Barakat, F., Vansteelandt, M., Triastuti, A., Lamer, A. Le, \& Parianos, G. (2018). Three new bisthiodiketopiperazines with two spirocyclic centers isolated from the endophytic fungus Botryosphaeria mamane. 3td Symposium International AFERP STOLON.

Bertrand, S., Azzollini, A., Schumpp, O., Bohni, N., Schrenzel, J., Monod, M., Gindro, K., \& Wolfender, J. L. (2014). Multi-well fungal co-culture for de novo metabolite-induction in time-series studies 
based on untargeted metabolomics. Molecular BioSystems, 10(9), 2289-2298. https://doi.org/10.1039/c4mb00223g

Bertrand, S., Bohni, N., Schnee, S., Schumpp, O., Gindro, K., \& Wolfender, J. L. (2014). Metabolite induction via microorganism co-culture: A potential way to enhance chemical diversity for drug discovery. Biotechnology Advances, 32(6), 1180-1204.

https://doi.org/10.1016/j.biotechadv.2014.03.001

Bertrand, S., Schumpp, O., Bohni, N., Bujard, A., Azzollini, A., Monod, M., Gindro, K., \& Wolfender, J. L. (2013). Detection of metabolite induction in fungal co-cultures on solid media by highthroughput differential ultra-high pressure liquid chromatography-time-of-flight mass spectrometry fingerprinting. Journal of Chromatography A, 1292, 219-228.

https://doi.org/10.1016/j.chroma.2013.01.098

Bertrand, S., Schumpp, O., Bohni, N., Monod, M., Gindro, K., \& Wolfender, J.-L. (2013). De Novo Production of Metabolites by Fungal Co-culture of Trichopyton rubrum and Bionetrica ochroleuca. J. Nat. Prod., 76(6), 1157-1165. https://doi.org/10.1021/np400258f

Bode, H. B., Bethe, B., Höfs, R., \& Zeeck, A. (2002). Big effects from small changes: Possible ways to explore nature's chemical diversity. ChemBioChem, 3(7), 619-627. https://doi.org/10.1002/1439-7633(20020703)3:7<619::AID-CBIC619>3.0.C0;2-9

Brady, S. F., Bondi, S. M., \& Clardy, J. (2001). The guanacastepenes: A highly diverse family of secondary metabolites produced by an endophytic fungus. Journal of the American Chemical Society, 123(40), 9900-9901. https://doi.org/10.1021/ja016176y

Brakhage, A. A., Bergmann, S., Schuemann, J., Scherlach, K., Schroeckh, V., \& Hertweck, C. (2009). Fungal Genome Mining and Activation of Silent Gene Clusters. Physiology and Genetics, 297303. https://doi.org/10.1007/978-3-642-00286-1_14

Brakhage, A. A., \& Schroeckh, V. (2011). Fungal secondary metabolites - Strategies to activate silent gene clusters. Fungal Genetics and Biology, 48(1), 15-22. https://doi.org/10.1016/j.fgb.2010.04.004

Butt TM, Jackson C, M. N. (2001). Fungi as biocontrol agents. Progress, problems and potential. CABI Publishing.

Calcul, L., Waterman, C., Ma, W. S., Lebar, M. D., Harter, C., Mutka, T., Morton, L., Maignan, P., Van Olphen, A., Kyle, D. E., Vrijmoed, L., Pang, K. L., Pearce, C., \& Baker, B. J. (2013). Screening mangrove endophytic fungi for antimalarial natural products. Marine Drugs, 11(12), 50365050. https://doi.org/10.3390/md11125036

Casella, T. M., Eparvier, V., Mandavid, H., Bendelac, A., Odonne, G., Dayan, L., Duplais, C., Espindola, L. S., \& Stien, D. (2013). Antimicrobial and cytotoxic secondary metabolites from tropical leaf endophytes: Isolation of antibacterial agent pyrrocidine C from Lewia infectoria SNB-GTC2402. Phytochemistry, 96(2013), 370-377. https://doi.org/10.1016/j.phytochem.2013.10.004

Chagas, F. O., Dias, L. G., \& Pupo, M. T. (2013). A Mixed Culture of Endophytic Fungi Increases Production of Antifungal Polyketides. J Chem Ecol, 39(10), 1335-1342. https://doi.org/10.1007/s10886-013-0351-7

Chen, H.-J., Awakawa, T., Sun, J.-Y., Wakimoto, T., \& Abe, I. (2013). Epigenetic modifier-induced biosynthesis of novel fusaric acid derivatives in endophytic fungi from Datura stramonium $\mathrm{L}$. Natural Products and Bioprospecting, 3(1), 20-23. https://doi.org/10.1007/s13659-0130010-2

Cheng, M. J., Wu, M. Der, Yanai, H., Su, Y. S., Chen, I. S., Yuan, G. F., Hsieh, S. Y., \& Chen, J. J. (2012). Secondary metabolites from the endophytic fungus Biscogniauxia formosana and their antimycobacterial activity. Phytochemistry Letters, 5(3), 467-472. https://doi.org/10.1016/j.phytol.2012.04.007

Chung, Y. M., El-Shazly, M., Chuang, D. W., Hwang, T. L., Asai, T., Oshima, Y., Ashour, M. L., Wu, Y. C., \& Chang, F. R. (2013). Suberoylanilide hydroxamic acid, a histone deacetylase inhibitor, induces 
the production of anti-inflammatory cyclodepsipeptides from Beauveria felina. Journal of Natural Products, 76(7), 1260-1266. https://doi.org/10.1021/np400143j

Corrêa, R. C. G., Rhoden, S. A., Mota, T. R., Azevedo, J. L., Pamphile, J. A., de Souza, C. G. M., Polizeli, M. de L. T. de M., Bracht, A., \& Peralta, R. M. (2014). Endophytic fungi: expanding the arsenal of industrial enzyme producers. Journal of Industrial Microbiology and Biotechnology, 41(10), 1467-1478. https://doi.org/10.1007/s10295-014-1496-2

Debbab, A., Aly, A. H., \& Proksch, P. (2013). Mangrove derived fungal endophytes - A chemical and biological perception. Fungal Diversity, 61(1), 1-27. https://doi.org/10.1007/s13225-0130243-8

Deshmukh, Sunil K., Gupta, M. K., Prakash, V., \& Saxena, S. (2018). Endophytic fungi: A source of potential antifungal compounds. Journal of Fungi, 4(3). https://doi.org/10.3390/jof4030077

Deshmukh, Sunil Kumar, Verekar, S. A., \& Bhave, S. V. (2014). Endophytic fungi: A reservoir of antibacterials. In Frontiers in Microbiology (Vol. 5, Issue DEC, pp. 1-43). https://doi.org/10.3389/fmicb.2014.00715

Dettrakul, S., Kittakoop, P., Isaka, M., Nopichai, S., Suyarnsestakorn, C., Tanticharoen, M., \& Thebtaranonth, Y. (2003). Antimycobacterial pimarane diterpenes from the fungus Diaporthe sp. Bioorganic and Medicinal Chemistry Letters, 13(7), 1253-1255.

https://doi.org/10.1016/S0960-894X(03)00111-2

Dhankhar, S., Kumar, S., Sandeep, D., \& Yadav, J. P. (2012). Antioxidant Activity of fungal endophytes isolated From Salvadora Oleoides Decne. International Journal of Pharmacy and Pharmaceutical Sciences, 4(2), 380-385.

do Nascimento, A. M., Soares, M. G., da Silva Torchelsen, F. K. V., de Araujo, J. A. V., Lage, P. S., Duarte, M. C., Andrade, P. H. R., Ribeiro, T. G., Coelho, E. A. F., \& do Nascimento, A. M. (2015). Antileishmanial activity of compounds produced by endophytic fungi derived from medicinal plant Vernonia polyanthes and their potential as source of bioactive substances. World Journal of Microbiology and Biotechnology, 31(11), 1793-1800. https://doi.org/10.1007/s11274-0151932-0

Ferreira, M. C., Vieira, M. de L. A., Zani, C. L., Alves, T. M. de A., Junior, P. A. S., Murta, S. M. F., Romanha, A. J., Gil, L. H. V. G., Carvalho, A. G. de O., Zilli, J. E., Vital, M. J. S., Rosa, C. A., \& Rosa, L. H. (2015). Molecular phylogeny, diversity, symbiosis and discover of bioactive compounds of endophytic fungi associated with the medicinal Amazonian plant Carapa guianensis Aublet (Meliaceae). Biochemical Systematics and Ecology, 59, 36-44. https://doi.org/10.1016/j.bse.2014.12.017

Flewelling, A. J., Bishop, A. I., Johnson, J. A., \& Gray, C. A. (2015). Polyketides from an endophytic aspergillus fumigatus isolate inhibit the growth of mycobacterium tuberculosis and MRSA. Natural Product Communications, 10(10), 1661-1662. https://doi.org/10.1177/1934578x1501001009

Flores, A. C., Pamphile, J. A., Sarragiotto, M. H., \& Clemente, E. (2013). Production of 3-nitropropionic acid by endophytic fungus Phomopsis longicolla isolated from Trichilia elegans A. JUSS ssp. elegans and evaluation of biological activity. World Journal of Microbiology and Biotechnology, 29(5), 923-932. https://doi.org/10.1007/s11274-013-1251-2

Gao, F. K., Dai, C. C., \& Liu, X. Z. (2010). Mechanisms of fungal endophytes in plant protection against pathogens. African Journal of Microbiology Research, 4(13), 1346-1351.

Giri C, Ochieng E, Tieszen LL, Zhu Z, Singh A, Loveland T, et al. (2011). Status and distribution of mangrove forests of the world using earth observation satellite data. Global Ecology and Biogeography, 20(1), 154-159. https://doi.org/10.1111/j.1466-8238.2010.00584.x

González-Menéndez, V., Pérez-Bonilla, M., Pérez-Victoria, I., Martín, J., Muñoz, F., Reyes, F., Tormo, J. R., \& Genilloud, O. (2016). Multicomponent analysis of the differential induction of secondary metabolite profiles in fungal endophytes. Molecules, 21(2). 
https://doi.org/10.3390/molecules21020234

Gupta, S., Chaturvedi, P., Kulkarni, M. G., \& Van Staden, J. (2020). A critical review on exploiting the pharmaceutical potential of plant endophytic fungi. Biotechnology Advances, 107462. https://doi.org/10.1016/j.biotechadv.2019.107462

Heinig, U., Scholz, S., \& Jennewein, S. (2013). Getting to the bottom of Taxol biosynthesis by fungi. Fungal Diversity, 60(1), 161-170. https://doi.org/10.1007/s13225-013-0228-7

Herre, E. A., Van Bael, S. A., Maynard, Z., Robbins, N., Bischoff, J., Arnold, A. E., Rojas, E., Mejia, L. C., Cordero, R. A., Woodward, C., \& Kyllo, D. A. (2009). Tropical plants as chimera: some implications of foliar endophytic fungi for the study of host-plant defence, physiology and genetics. Biotic Interactions in the Tropics, January, 226-238.

https://doi.org/10.1017/cbo9780511541971.010

Higginbotham, S. J., Arnold, A. E., Ibañez, A., Spadafora, C., Coley, P. D., \& Kursar, T. A. (2013). Bioactivity of Fungal Endophytes as a Function of Endophyte Taxonomy and the Taxonomy and Distribution of Their Host Plants. PLOS ONE, 8(9). https://doi.org/10.1371/journal.pone.0073192

Hipol, R. M., Magtoto, L. M., Tamang, S. M. A., \& Amor, M. (2014). Antioxidant Activities of Fungal Endophytes Isolated from Strawberry Fragaria x Ananassa Fruit. Electronic Journal of Biology, 10(4), 107-112.

Hu, M., Yang, X. Q., Wan, C. P., Wang, B. Y., Yin, H. Y., Shi, L. J., Wu, Y. M., Yang, Y. Bin, Zhou, H., \& Ding, Z. T. (2018). Potential antihyperlipidemic polyketones from endophytic: Diaporthe sp. JC-J7 in Dendrobium nobile. RSC Advances, 8(73), 41810-41817. https://doi.org/10.1039/c8ra08822e

Huang, W.-Y., Cai, Y.-Z., Xing, J., Corke, H., \& Sun, M. (2007). A Potential Antioxidant Resource: Endophytic Fungi from Medicinal Plants. Economic Botany, 61(1), 14-30. https://doi.org/10.1663/0013-0001(2007)61[14:APAREF]2.0.C0;2

Hussain, H., Akhtar, N., Draeger, S., Schulz, B., Pescitelli, G., Salvadori, P., Antus, S., Kurtán, T., \& Krohn, K. (2009). New bioactive 2,3-epoxycyclohexenes and isocoumarins from the endophytic fungus Phomopsis sp. from laurus azorica. European Journal of Organic Chemistry, 5, 749-756. https://doi.org/10.1002/ejoc.200801052

Hussain, H., Jabeen, F., Krohn, K., Al-Harrasi, A., Ahmad, M., Mabood, F., Shah, A., Badshah, A., Rehman, N. U., Green, I. R., Ali, I., Draeger, S., \& Schulz, B. (2015). Antimicrobial activity of two mellein derivatives isolated from an endophytic fungus. Medicinal Chemistry Research, 24(5), 2111-2114. https://doi.org/10.1007/s00044-014-1250-3

Isaka, M., Chinthanom, P., Boonruangprapa, T., Rungjindamai, N., \& Pinruan, U. (2010). Eremophilane-type sesquiterpenes from the fungus xylaria sp. BCC 21097. Journal of Natural Products, 73(4), 683-687. https://doi.org/10.1021/np100030x

James, J., \& Dubery, I. (2011). Identification and Quantification of Triterpenoid Centelloids in Centella asiatica ( $L \quad$.) Urban by Densitometric TLC. 24, 82-87. https://doi.org/10.1556/JPC.24.2011.1.16

Justice, M. C., Hsu, M. J., Tse, B., Ku, T., Balkovec, J., Schmatz, D., \& Nielsen, J. (1998). Elongation factor 2 as a novel target for selective inhibition of fungal protein synthesis. Journal of Biological Chemistry, 273(6), 3148-3151. https://doi.org/10.1074/jbc.273.6.3148

Kaul, S., Gupta, S., Ahmed, M., \& Dhar, M. K. (2012). Endophytic fungi from medicinal plants: A treasure hunt for bioactive metabolites. Phytochemistry Reviews, 11(4), 487-505. https://doi.org/10.1007/s11101-012-9260-6

Kavanagh, K. (2005). Fungi: Biology and Applications. Chichester, UK: Wiley

Kementerian Riset Teknologi dan Pendidikan Tinggi. (2017). Rencana Induk Riset Nasional Tahun 2017-2045. http://rirn.ristekdikti.go.id

Kouipou, R. M., \& Boyom, F. F. (2019). Endophytic fungi from terminalia species: a comprehensive review. Journal of Fungi, 5(2). https://doi.org/10.3390/jof5020043 
Kumar, S., \& Kaushik, N. (2012). Metabolites of endoph2005ytic fungi as novel source of biofungicide: A review. Phytochemistry Reviews, 11(4), 507-522. https://doi.org/10.1007/s11101-013-9271-y

Kumar, S. N., Sreekala, S. R., Chandrasekaran, D., Nambisan, B., \& Anto, R. J. (2014). Biocontrol of Aspergillus species on peanut kernels by antifungal diketopiperazine producing Bacillus cereus associated with entomopathogenic nematode. PLOS ONE, 9(8). https://doi.org/10.1371/journal.pone.0106041

Kurt, T., Hartmann, R., Lin, W., Herve, S., Attila, M., Daletos, G., \& Proksch, P. (2016). Inducing secondary metabolite production by the endophytic fungus Chaetomium sp . through fungalbacterial co-culture and epigenetic modification. 72, 6340-6347. https://doi.org/10.1016/j.tet.2016.08.022

Kusari, S., Hertweck, C., \& Spiteller, M. (2012). Chemical ecology of endophytic fungi: Origins of secondary metabolites. Chemistry and Biology, 19(7), 792-798. https://doi.org/10.1016/j.chembiol.2012.06.004

Kyekyeku, J. O., Kusari, S., Adosraku, R. K., Bullach, A., Golz, C., Strohmann, C., \& Spiteller, M. (2017). Antibacterial secondary metabolites from an endophytic fungus, Fusarium solani JK10. Fitoterapia, 119(February), 108-114. https://doi.org/10.1016/j.fitote.2017.04.007

Lamoth, F., Juvvadi, P. R., \& Steinbach, W. J. (2015). Histone deacetylase inhibition as an alternative strategy against invasive aspergillosis. Frontiers in Microbiology, 6(FEB), 4-9. https://doi.org/10.3389/fmicb.2015.00096

Li, J. Y., Sidhu, R. S., Ford, E. J., Long, D. M., Hess, W. M., \& Strobel, G. A. (1998). The induction of taxol production in the endophytic fungus - Periconia sp from Torreya grandifolia. Journal of Industrial Microbiology and Biotechnology, 20(5), 259-264. https://doi.org/10.1038/sj.jim.2900521

Li, M. Y., Xiao, Q., Pan, J. Y., \& Wu, J. (2009). Natural products from semi-mangrove flora: Source, chemistry and bioactivities. Natural Product Reports, 26(2), 281-298. https://doi.org/10.1039/b816245j

Li, S. J., Zhang, X., Wang, X. H., \& Zhao, C. Q. (2018). Novel natural compounds from endophytic fungi with anticancer activity. European Journal of Medicinal Chemistry, 156, 316-343. https://doi.org/10.1016/j.ejmech.2018.07.015

Lim, F. Y., Sanchez, J. F., Wang, C. C. C., Keller, N. P., Fang Yun Lim, James F. Sanchez, Clay C.C. Wang, N. P. K., Lim, F. Y., Sanchez, J. F., Wang, C. C. C., \& Keller, N. P. (2012). Toward awakening cryptic secondary metabolite gene clusters in filamentous fungi. Methods in Enzymology, 517, 303-324. https://doi.org/10.1016/B978-0-12-404634-4.00015-2

Martín-Rodríguez, A., Reyes, F., Martín, J., Pérez-Yépez, J., León-Barrios, M., Couttolenc, A., Espinoza, C., Trigos, Á., Martín, V., Norte, M., \& Fernández, J. (2014). Inhibition of Bacterial Quorum Sensing by Extracts from Aquatic Fungi: First Report from Marine Endophytes. Marine Drugs, 12(11), 5503-5526. https://doi.org/10.3390/md12115503

Martínez-luis, S., Cherigo, L., Higginbotham, S., Arnold, E., Spadafora, C., Ibañez, A., Gerwick, W. H., \& Cubilla-rios, L. (2011). Screening and evaluation of antiparasitic and in vitro anticancer activities of Panamanian endophytic fungi. June. https://doi.org/10.2436/20.1501.01.139

Martins, M. B., \& Carvalho, I. (2007). Diketopiperazines: biological activity and synthesis. Tetrahedron, 63(40), 9923-9932. https://doi.org/10.1016/j.tet.2007.04.105

Ministry of Environment and Forestry of Indonesia. (2014). The Fifth National Report of Indonesia to the Convention on Biological Diversity [Internet]. https://www.cbd.int/doc/world/id/id-nr05-en.pdf

Moreno, E., Varughese, T., Spadafora, C., Arnold, a. E., Coley, P. D., Kursar, T. a., Gerwick, W. H., \& Luis-Cubilla-Rios. (2011). Chemical constituents of the new endophytic fungus Mucosphaerella sp. nov. and their anti-parasitic activity. Natural Prodroduct Communiations, 6(6), 835-840. 
Mousa, W. K., \& Raizada, M. N. (2013). The Diversity of Anti-Microbial Secondary Metabolites Produced by Fungal Endophytes: An Interdisciplinary Perspective. Frontiers in Microbiology, 4(March), 1-18. https://doi.org/10.3389/fmicb.2013.00065

Netzker, T., Fischer, J., Weber, J., Mattern, D. J., König, C. C., Valiante, V., Schroeckh, V., \& Brakhage, A. A. (2015). Microbial communication leading to the activation of silent fungal secondary metabolite gene clusters. Frontiers in Microbiology, 6(MAR), 1-13. https://doi.org/10.3389/fmicb.2015.00299

Newman, D. J., \& Cragg, G. M. (2012). Natural products as sources of new drugs over the 30 years from 1981 to 2010. Journal of Natural Products, 75(3), 311-335. https://doi.org/10.1021/np200906s

Newman, D. J., \& Cragg, G. M. (2016). Natural Products as Sources of New Drugs from 1981 to 2014. Journal of Natural Products, 79(3), 629-661. https://doi.org/10.1021/acs.jnatprod.5b01055

Nützmann, H. W., Schroeckh, V., \& Brakhage, A. A. (2012). Regulatory cross talk and microbial induction of fungal secondary metabolite gene clusters. Methods in Enzymology, 517, 325-341. https://doi.org/10.1016/B978-0-12-404634-4.00016-4

Osorio, J. A., Crous, C. J., de Beer, Z. W., Wingfield, M. J., \& Roux, J. (2017). Endophytic Botryosphaeriaceae, including five new species, associated with mangrove trees in South Africa. Fungal Biology, 121(4), 361-393. https://doi.org/10.1016/j.funbio.2016.09.004

Patil, M., Patil, R., Mohammad, S., \& Maheshwari, V. (2017). Bioactivities of phenolics-rich fraction from Diaporthe arengae TATW2, an endophytic fungus from Terminalia arjuna (Roxb.). Biocatalysis and Agricultural Biotechnology, 10(February), 396-402. https://doi.org/10.1016/j.bcab.2017.05.002

Pompeng, P., Sommit, D., Sriubolmas, N., Ngamrojanavanich, N., Matsubara, K., \& Pudhom, K. (2013). Antiangiogenetic effects of anthranoids from Alternaria sp., an endophytic fungus in a Thai medicinal plant Erythrina variegata. Phytomedicine : International Journal of Phytotherapy and Phytopharmacology, 20(10), 918-922. https://doi.org/10.1016/j.phymed.2013.03.019

Pu, X., Li, G., Xiao, Q., Yi, J., Tian, Y., Zhang, G., Zhao, L., \& Luo, Y. (2013). Isolation, attenuation and secondary metabolites of attenuated camptothecin-producing endophytic fungus Aspergillus sp. LY013 from Camptotheca acuminata. Yingyong Yu Huanjing Shengwu Xuebao, 19(5), 787793. https://doi.org/10.3724/SP.J.1145.2013.00787

Reen, F. J., Romano, S., Dobson, A. D. W., \& O'Gara, F. (2015). The sound of silence: Activating silent biosynthetic gene clusters in marine microorganisms. Marine Drugs, 13(8), 4754-4783. https://doi.org/10.3390/md13084754

Rozpadek, P., Domka, A., \& Turnau, K. (2017). Mycorrhizal Fungi and Accompanying Microorganisms in Improving Phytoremediation Techniques. In J. Dighton \& J. F. White (Eds.), The Fungal Community Its Organization and Role in the Ecosystem (4th ed., pp. 419-432). CRC press. https://doi.org/10.1201/9781315119496-30

Rukachaisirikul, V., Sommart, U., Phongpaichit, S., Sakayaroj, J., \& Kirtikara, K. (2008). Metabolites from the endophytic fungus Phomopsis sp. PSU-D15. Phytochemistry, 69(3), 783-787. https://doi.org/10.1016/j.phytochem.2007.09.006

Sappapan, R., Sommit, D., Ngamrojanavanich, N., Pengpreecha, S., Wiyakrutta, S., Sriubolmas, N., \& Pudhom, K. (2008). 11-Hydroxymonocerin from the plant endophytic fungus Exserohilum rostratum (Journal of Natural Products (2008) 71, (1657)). Journal of Natural Products, 71(12), 2080. https://doi.org/10.1021/np8006167

Selim, K., El-beih, A., Abdel-rahman, T., \& El-diwany, A. (2012). Biology of Endophytic Fungi. Current Research in Environmental and Applied Mycology, 2(1), 31-82. https://doi.org/10.5943/cream/2/1/3

Serrano, R., González-Menéndez, V., Rodríguez, L., Martín, J., Tormo, J. R., \& Genilloud, O. (2017). Coculturing of fungal strains against Botrytis cinerea as a model for the induction of chemical 
diversity and therapeutic agents. Frontiers in Microbiology, 8(APR), 1-15. https://doi.org/10.3389/fmicb.2017.00649

Seto, Y., Takahashi, K., Matsuura, H., Kogami, Y., Yada, H., Yoshihara, T., \& Nabeta, K. (2007). Novel cyclic peptide, epichlicin, from the endophytic fungus, Epichloe typhina. Bioscience, Biotechnology and Biochemistry, 71(6), 1470-1475. https://doi.org/10.1271/bbb.60700

Sieber, T. N. (2007). Endophytic fungi in forest trees: are they mutualists? Fungal Biology Reviews, 21(2-3), 75-89. https://doi.org/10.1016/j.fbr.2007.05.004

Siless, G. E., Gallardo, G. L., Rodriguez, M. A., Rincón, Y. A., Godeas, A. M., \& Cabrera, G. M. (2018). Metabolites from the Dark Septate Endophyte Drechslera sp. Evaluation by LC/MS and Principal Component Analysis of Culture Extracts with Histone Deacetylase Inhibitors. Chemistry and Biodiversity, 15(8). https://doi.org/10.1002/cbdv.201800133

Srinivasan, R., Devi, K. R., Kannappan, A., Pandian, S. K., \& Ravi, A. V. (2016). Piper betle and its bioactive metabolite phytol mitigates quorum sensing mediated virulence factors and biofilm of nosocomial pathogen Serratia marcescens in vitro. Journal of Ethnopharmacology, 193(May), 592-603. https://doi.org/10.1016/j.jep.2016.10.017

Stierle, A., Strobel, G., \& Stierle, D. (1993). Taxol and Taxane Production by Taxomyces andreanae, an Endophytic Fungus of Pacific Yew. Science, 260, 214-216. https://doi.org/10.1126/science.8097061

Strobel, G. a. (2003). Endophytes as sources of bioactive products. Microbes and Infection, 5(6), 535-544. https://doi.org/10.1016/S1286-4579(03)00073-X

Strobel, G. a., Miller, R. V., Martinez-Miller, C., Condron, M. M., Teplow, D. B., \& Hess, W. M. (1999). Cryptocandin, a potent antimycotic from the endophytic fungus Cryptosporiopsis cf. quercina. Microbiology, 145(1 999), 1919-1926. https://doi.org/10.1099/13500872-145-8-1919

Strobel, G., \& Daisy, B. (2003). Bioprospecting for Microbial Endophytes and Their Natural Products Bioprospecting for Microbial Endophytes and Their Natural Products. 67(4). https://doi.org/10.1128/MMBR.67.4.491

Suryanarayanan, T. S., Thirunavukkarasu, N., Govinda Rajulu, M. B., Sasse, F., Jansen, R., \& Murali, T. S. (2009). Fungal Endophytes and Bioprospecting: An appeal for a concerted effort. Fungal Biology Reviews, 23(1-2), 9-19.

Tansuwan, S., Pornpakakul, S., Roengsumran, S., Petsom, A., Muangsin, N., Sihanonta, P., \& Chaichit, N. (2007). Antimalarial benzoquinones from an endophytic fungus, Xylaria sp. Journal of Natural Products, 70(10), 1620-1623. https://doi.org/10.1021/np0701069

Toghueo, R. M. K., \& Boyom, F. F. (2020). Endophytic Penicillium species and their agricultural, biotechnological, and pharmaceutical applications. In 3 Biotech (Vol. 10, Issue 3). Springer International Publishing. https://doi.org/10.1007/s13205-020-2081-1

Triastuti, A., Vansteelandt, M., Barakat, F., Trinel, M., Jargeat, P., Fabre, N., Amasifuen Guerra, C. A., Mejia, K., Valentin, A., \& Haddad, M. (2019). How Histone Deacetylase Inhibitors Alter the Secondary Metabolites of Botryosphaeria mamane, an Endophytic Fungus Isolated from Bixa orellana. Chemistry and Biodiversity, 16(4). https://doi.org/10.1002/cbdv.201800485

von Rintelen, K., Arida, E., \& Häuser, C. (2017). A review of biodiversity-related issues and challenges in megadiverse Indonesia and other Southeast Asian countries. Research Ideas and Outcomes, 3(September), e20860. https://doi.org/10.3897/rio.3.e20860

Wang, C., Liu, H., Li, J., \& Sun, H. (2014). Degradation of PAHs in soil by Lasiodiplodia theobromae and enhanced benzo[a]pyrene degradation by the addition of Tween-80. In Environmental Science and Pollution Research (Vol. 21). https://doi.org/10.1007/s11356-014-3050-1

Wang, F. W., Ye, Y. H., Ding, H., Chen, Y. X., Tan, R. X., \& Song, Y. C. (2010). Benzophenones from Guignardia sp. IFB-E028, an endophyte on Hopea hainanensis. Chemistry and Biodiversity, 7(1), 216-220. https://doi.org/10.1002/cbdv.200800353

Wang, Q.-X., Li, S.-F., Zhao, F., Dai, H.-Q., Bao, L., Ding, R., Gao, H., Zhang, L.-X., Wen, H.-A., \& Liu, H.-W. 
(2011). Chemical constituents from endophytic fungus Fusarium oxysporum. Fitoterapia, 82(5), 777-781. https://doi.org/10.1016/j.fitote.2011.04.002

World Health Organization. (2020). Tuberculosis (Issue October 2019).

Xiao, J., Zhang, Q., Gao, Y., Tang, J., Zhang, A., \& Gao, J. (2014). Secondary Metabolites from the Endophytic Botryosphaeria dothidea of Melia azedarach and Their Antifungal, Antibacterial, Antioxidant, and Cytotoxic Activities. J. Agric. Food Chem, 62, 3584-3590. https://doi.org/10.1021/jf500054f

Yang, X. L., Huang, L., \& Ruan, X. L. (2014). Epigenetic modifiers alter the secondary metabolite composition of a plant endophytic fungus, Pestalotiopsis crassiuscula obtained from the leaves of Fragaria chiloensis. Journal of Asian Natural Products Research, 16(4), 412-417. https://doi.org/10.1080/10286020.2014.881356

Yang, Y., Zhao, H., Barrero, R. A., Zhang, B., Sun, G., Wilson, I. W., Xie, F., Walker, K. D., Parks, J. W., Bruce, R., Guo, G., Chen, L., Zhang, Y., Huang, X., Tang, Q., Liu, H., Bellgard, M. I., Qiu, D., Lai, J., \& Hoffman, A. (2014). Genome sequencing and analysis of the paclitaxel-producing endophytic fungus Penicillium aurantiogriseum NRRL 62431. BMC Genomics, 15(1), 1-14. https://doi.org/10.1186/1471-2164-15-69

Yao, L., Zhu, L.-P., Xu, X.-Y., Tan, L.-L., Sadilek, M., Fan, H., Hu, B., Shen, X.-T., Yang, J., Qiao, B., \& Yang, S. (2016). Discovery of novel xylosides in co-culture of basidiomycetes Trametes versicolor and Ganoderma applanatum by integrated metabolomics and bioinformatics. Scientific Reports, 6(August), 33237. https://doi.org/10.1038/srep33237

Zhu, S.-S., Zhang, Y.-S., Sheng, X.-H., Xu, M., Wu, S.-S., Shen, Y.-M., Huang, Y.-J., Wang, Y., \& Shi, Y.-Q. (2015). Deacetyl-mycoepoxydiene, isolated from plant endophytic fungi Phomosis sp. demonstrates anti-microtubule activity in MCF-7 cells. Biomedicine \& Pharmacotherapy, 69, 82-89. https://doi.org/10.1016/j.biopha.2014.11.020 